\title{
Attenuation Coefficient and Propagation Speed Estimates of Rat and Pig Intercostal Tissue as a Function of Temperature
}

\author{
Rene T. Towa, Rita J. Miller, Leon A. Frizzell, Senior Member, IEEE, James F. Zachary, \\ and William D. O'Brien, Jr., Fellow, IEEE
}

\begin{abstract}
Attenuation coefficient and propagation speed of intercostal tissues were estimated as functions of temperature $\left(22,30\right.$, and $\left.37^{\circ} \mathrm{C}\right)$ from fresh chest walls from eight 10- to 11-week-old female Sprague-Dawley (SD) rats, eight 21- to 24-week-old female Long-Evans (LE) rats, and ten 6- to 10-week-old mixed sex Yorkshire (York) pigs. The primary purpose of the study was to estimate the temperature dependence of the intercostal tissue's attenuation coefficient so that accurate estimates of the in situ (at the pleural surface) acoustic pressure levels could be made for our ultrasound-induced lung hemorrhage studies. The attenuation coefficient of intercostal tissue for both species was independent of the temperature at the discrete frequencies of $3.1 \mathrm{MHz}\left(-0.0076,0.0065\right.$, and $0.016 \mathrm{~dB} / \mathrm{cm} /{ }^{\circ} \mathrm{C}$ for $\mathrm{SD}$ rats, $\mathrm{LE}$ rats, and York pigs, respectively) and $6.2 \mathrm{MHz}$ $\left(-0.015,0.014\right.$, and $0.014 \mathrm{~dB} / \mathrm{cm} /{ }^{\circ} \mathrm{C}$ for $\mathrm{SD}$ rats, $\mathrm{LE}$ rats, and York pigs, respectively). However, the temperaturedependent regressions yielded a significant temperature dependency of the intercostal tissue attenuation coefficients in $\mathrm{SD}$ and LE rats (over the 3.1 to $9.6 \mathrm{MHz}$ frequency range); there was no temperature dependency in York pigs (over the 3.1 to $8.6 \mathrm{MHz}$ frequency range). There was no significant temperature dependency of the intercostal tissue propagation speed in SD rats; there was a temperature dependency in LE rats and York pigs $(-0.59,-1.6$, and $-2.9 \mathrm{~m} / \mathrm{s} /{ }^{\circ} \mathrm{C}$ for $\mathrm{SD}$ rats, LE rats, and York pigs, respectively). Even though the attenuation coefficient's temperature dependency was significant from the linear regression functions, the differences were not very great $(-0.040$ to $-0.13,0.011$ to 0.18 , and 0.055 to $0.10 \mathrm{~dB} / \mathrm{cm} /{ }^{\circ} \mathrm{C}$ for $\mathrm{SD}$ rats, LE rats, and York pigs, respectively, over the data frequency range). These findings suggest that it is not necessary to determine the attenuation coefficient of intercostal tissue at body temperature $\left(37^{\circ} \mathrm{C}\right)$, but rather it is sufficient to determine the attenuation coefficient at room temperature $\left(22^{\circ} \mathrm{C}\right)$, a much easier experimental procedure.
\end{abstract}

\section{INTRODUCTION}

$\mathrm{T}$ HERE have been numerous ultrasound-induced lung hemorrhage studies [1]-[21]. These studies, all of which produced lung damage, involved exposing the lungs

Manuscript received August 27, 2001; accepted May 15, 2002. This work was supported by NIH Grant HL58218 awarded to WDO and JFZ.

R. T. Towa, R. J. Miller, L. A. Frizzell, and W. D. O'Brien, Jr., are with the Bioacoustics Research Laboratory, Department of Electrical and Computer Engineering, University of Illinois at UrbanaChampaign, Urbana, IL 61801 (e-mail: wdo@uiuc.edu)

L. A. Frizzell, J. F. Zachary, and W. D. O'Brien, Jr. are also with the Bioengineering Program, University of Illinois at UrbanaChampaign, Urbana, IL 61801. of various animals as a function of ultrasound frequency, species, or age to pulsed ultrasound in vivo. For these studies, the ultrasound propagation path is between the ribs, and this tissue region is called the intercostal tissue. Between the skin and lung surfaces, the intercostal tissue consists of the following: skin, panniculus muscle, subcutaneous adipose tissue [fat], intercostal muscle, and parietal pleura. Under the in vivo exposure conditions, it was likely that the intercostal tissue was near or at a temperature of around $37^{\circ} \mathrm{C}$. Some of these studies reported the lung damage findings in terms of water-based acoustic pressure measurements, that is, in terms of the incident acoustic pressure on the skin surface [1]-[5], [7], [9], [11], [13], [14]. Other studies estimated the acoustic pressures at the lung surface by using the diagnostic ultrasound system displayed quantities [6], estimated intercostal tissue attenuation coefficient [7], [8], [12], or measured intercostal tissue attenuation coefficient at room temperature [10], [15]-[21]. In order to undersand the mechanism(s) of ultrasound-induced lung hemorrhage, the exposure and/or dose must be estimated properly at the lung surface. Currently it is difficult to estimate the in situ (at the pleural surface) exposure and/or dose in most of the published studies. This estimation would require at least an understanding of the temperature-dependent attenuation coefficient of intercostal tissue. The study reported herein determines the temperature-dependent attenuation coefficient and propagation speed of intercostal tissue in two strains of rats and in one breed of pigs.

\section{Materials AND Methods}

\section{A. Animals and Animal Related Procedures}

The experimental protocol was approved by the Laboratory Animal Care Advisory Committee at the University of Illinois at Urbana-Champaign and satisfied all campus and National Institutes of Health rules for the humane use of laboratory animals. Rats were housed in an Association for Assessment and Accreditation of Laboratory Animal Care, Rockville, MD (AAALAC)-approved animal facility, placed in groups of 1-3 in polycarbonate cages with betachip bedding and wire bar lids, and provided food and water ad libitum. Pigs were housed in an AAALAC-approved animal facility, placed in groups of $1-5$ in raised deck pens 
with expanded metal floors, and provided food and water ad libitum. The AAALAC is a private, nonprofit organization that promotes the humane treatment of animals in science through a voluntary accreditation program.

The 26 chest walls used for attenuation coefficient and propagation speed estimates were no older than 24-hours post mortem $(\mathrm{pm})$ when the measurement process commenced. They were obtained from eight 10- to 11-week-old (mean \pm standard deviation) 218 \pm 14 -gm female SpragueDawley rats (Harlan Laboratories, Indianapolis, IN); eight 21- to 24-week-old 289 \pm 16 -gm female Long-Evans rats ( $\mathrm{Si}$ monsen Laboratories, Inc., Gilroy, CA); and ten 6- to 10week-old $18 \pm 7.6-\mathrm{kg}$ mixed sex Yorkshire pigs (University of Illinois Imported Swine Research Laboratory, Champaign, IL). Sprague-Dawley rats (SD) were euthanized by cervical dislocation while under anesthesia (ketamine hydrochloride $(87.0 \mathrm{mg} / \mathrm{kg})$ and xylazine $(13.0 \mathrm{mg} / \mathrm{kg})$ administered intraperitoneally) or by inhalation of compressed carbon dioxide gas. Long-Evans rats (LE) were euthanized by inhalation of carbon dioxide gas. Yorkshire pigs (York) were anesthetized with ketamine hydrochloride $(2.2 \mathrm{mg} / \mathrm{kg})$, xylazine $(2.2 \mathrm{mg} / \mathrm{kg})$, and tiletamine/zolazepam $(4.4 \mathrm{mg} / \mathrm{kg})$ administered intramuscularly and then euthanized by an intravenous injection of sodium pentobarbital $(0.22 \mathrm{~mL} / \mathrm{kg})$ while under anesthesia. The skin of the chest wall (left side for the SD rats, both sides for the LE rats, and both sides for the York pigs) was exposed by removing the hair with an electric clipper, followed by a depilatory agent (Nair ${ }^{\circledR}$, CarterWallace, Inc., New York, NY) to maximize sound transmission.

Following euthanasia, the thorax was opened via a median sternotomy. The sternotomy incision was continued along the ventral midline, with a curvilinear incision caudal to the last rib, which extended to the spinal column. This incision was then continued with a dorsal incision off midline, separating the chest wall from the spinal column. A curvilinear incision was made cranial to the first rib, connecting to the median sternotomy. The thickness of each intercostal tissue (skin, panniculus muscle, subcutaneous adipose tissue [fat], intercostal muscle, and parietal pleura) was measured with a digital micrometer (accuracy: $10 \mu \mathrm{m}$; Mitutoyo Corp., Kawasaki, Kanagawa, Japan) at the location of the attenuation measurements. Immediately following removal, the chest walls were placed in $0.9 \%$ sodium chloride solution then sealed in Glad-Lock ${ }^{\circledR}$ Zipper $^{\mathrm{TM}}$ bags (The Glad Products Co., Oakland, CA). Rat and pig chest walls were stored $(<2$ hours and $\leq 1$ day, respectively) at $4^{\circ} \mathrm{C}$ prior to measurements.

\section{B. Measurement and Analysis Techniques}

Identical experimental procedures were used for each species as described previously [22] using a standard through-transmission insertion-loss technique [23] to estimate the attenuation coefficient of the chest-wall intercostal tissues. The source transducer was driven by a low-power Panametrics 5800 pulser/receiver (Panamet- rics, Waltham, MA). The pulser/receiver operated in both the pulse-echo mode and the through-transmission mode, and its $2-\mathrm{kHz}$ pulse repetition frequency signal was fed to the source transducer. The source transducer, the hydrophone, and the specially designed holders supporting the chest-wall samples were immersed in degassed water maintained at a constant temperature. Water temperature was controlled by a proportional temperature controller (Yellow Springs Instrument Co., Inc., Yellow Springs, $\mathrm{OH}$ ) that was connected to three heaters (Waage Electric, Inc., Kenilworth, NJ). A precision thermometer in the water tank served as the temperature standard, and the three temperatures used in this study were $22 \pm 0.5$, $30 \pm 0.6$, and $37 \pm 0.3^{\circ} \mathrm{C}$. Pulse-echo ultrasonic fields of each focused, 19-mm-diameter source transducer (Panametrics, Inc., Waltham, MA) were characterized in degassed water $\left(22^{\circ} \mathrm{C}\right)$ by an established technique [24] prior to the experiments. The characterization of the transducer used for the pig chest walls yielded a center frequency of $7.0 \mathrm{MHz}$, a fractional bandwidth of $40 \%$, a focal length of $97 \mathrm{~mm}$, a -6 -dB focal beamwidth of $1.1 \mathrm{~mm}$, and a $-6-\mathrm{dB}$ depth of focus of $38 \mathrm{~mm}$. The characterization of the transducer used for the rat chest walls yielded a center frequency of $7.1 \mathrm{MHz}$, a fractional bandwidth of $43 \%$, a focal length of $51 \mathrm{~mm}$, a -6 - $\mathrm{dB}$ focal beamwidth of $0.56 \mathrm{~mm}$, and a $-6-\mathrm{dB}$ depth of focus of $9 \mathrm{~mm}$. The hydrophone was a 1$\mathrm{mm}^{2}$ bilaminar membrane hydrophone (Perceptron Model 804, Plymouth Meeting, PA). Holders for the chest walls were designed to accommodate two different species as a function of size. The sample was positioned between the broadbanded source transducer and the hydrophone. The hydrophone was placed as close as possible adjacent to the sample with the source transducer's focus at the location of the hydrophone.

The chest-wall samples were acclimatized to the water's temperature $\left(22,30\right.$, and $\left.37^{\circ} \mathrm{C}\right)$ for a period of at least 15 minutes after the water reached its target temperature. Data were acquired from 400 adjacent lateral positions over a 20-mm length in increments of $50 \mu \mathrm{m}$, for the rats. Data were acquired from 1000 adjacent lateral positions over a $50-\mathrm{mm}$ length in increments of $50 \mu \mathrm{m}$ for the pigs. The tissue site at which data were acquired was in the same location as the sound beam propagated in our ultrasound-induced lung hemorrhage exposures. Acquired data, at the same sample location, consisted of the through-transmission RF signals from which attenuation and speed were estimated, and pulse-echo RF signals for a B-mode image from which sample thickness was estimated. No bubbles were visible on the chest-wall samples; shaved and depilated chest walls were used. If bubbles had been present, it is hypothesized that they would have shown up on the B-mode image. However, no bubbles were visible by the naked eye or in the B-mode images of the chest-wall samples. If there was some skin with hair still remaining on the sample, the hair was removed prior to data acquisition. Also, even though the attenuation losses included surface reflection losses, they were considered to be insignificant and were not measured separately. 
Through-transmission reference data were acquired with degassed water between the source transducer and hydrophone. Reference data were acquired for each sample immediately following the acquisition of data from the chest-wall sample. The digitized pulse-echo and throughtransmission RF signals were transferred to a Sun UltraSparc (Sun Microsystems, Inc., Santa Clara, CA) workstation and analyzed using Matlab ${ }^{\circledR}$ (The MathWorks, Inc., Natick, MA).

Intercostal tissue propagation speed was determined from the transit time difference $(\Delta \mathrm{t})$ via a standard correlation integral technique between the water-path and through-tissue signals collected at the hydrophone, and from the sample thickness (d) determined from the Bmode image using:

$$
\mathrm{c}_{\text {sample }}=\frac{\mathrm{c}_{\text {reference }}}{1+\frac{\left(\mathrm{c}_{\text {reference }}\right)(\Delta \mathrm{t})}{\mathrm{d}}},
$$

where $c_{\text {reference }}$ is the propagation speed in water. The reference speed at the three temperatures was determined from a published equation [25] for distilled water, and the three reference speeds were $1488\left(22^{\circ} \mathrm{C}\right), 1509\left(30^{\circ} \mathrm{C}\right)$, and $1524\left(37^{\circ} \mathrm{C}\right) \mathrm{m} / \mathrm{s}$.

Intercostal tissue attenuation coefficient was determined from the insertion loss power spectrum divided by the thickness of the sample. The insertion loss power spectrum $(\mathrm{dB})$ was determined from the difference of two power spectra, the power spectrum of the received RF waveforms that propagated through water alone, and the power spectrum of the received RF waveforms that propagated through the interposed intercostal tissue sample. The insertion loss was divided by the thickness of the sample, as calculated from the B-mode image, to yield the attenuation coefficient (in $\mathrm{dB} / \mathrm{cm}$ ).

The intercostal tissue propagation speed that was determined from (1) has the potential to be in error. The intercostal tissue thickness $d$ was determined from the Bmode image, and a propagation speed of $1540 \mathrm{~m} / \mathrm{s}$ was used; the tissue propagation speed is, in general, different from $1540 \mathrm{~m} / \mathrm{s}$. Likewise, the intercostal tissue attenuation coefficient has the potential to be in error because its calculation was based on the same intercostal tissue thickness $d$ that was determined from the B-mode image. The errors were assessed against the intercostal tissue thicknesses measured with the digital micrometer, $d_{\text {measured }}$. For the revised propagation speed, $d_{\text {measured }}$ was used in (1); $c_{\text {reference }}$ and $\Delta t$ remained unchanged. For the revised attenuation coefficient, $\mathrm{d}_{\text {measured }}$ was used; insertion loss remained unchanged. The propagation speed errors ranged between -0.03 and $+0.25 \%$. The attenuation coefficient errors ranged between -3.5 and $+3.5 \%$. These errors were much less than the standard errors of propagation speed and attenuation coefficient. Therefore, no correction to the propagation speeds and attenuation coefficients as determined from the intercostal tissue thickness $d$ (from the B-mode image) was made.

\section{Statistics}

The linear regression analysis [26] yielded the $\pm 95 \%$ confidence bands for the regression line, the coefficient of determination, $\mathrm{r}^{2}$, the standard error of regression, SER, and the standard error of the slope, SES. It is common to see the attenuation coefficient normalized to frequency (in $\mathrm{dB} / \mathrm{cm}-\mathrm{MHz}$ ), which is the slope term for these regressions, to which the SES applies.

To test for equality of the three regression lines for each animal, an analysis of covariance F-test [27] was performed. The null model constrains the intercepts and slopes to be equal across different pig ages. The general model allows for unequal intercepts and slopes for the pig ages. If not rejected, the null model is used. If it is rejected, the general model is used.

\section{Results}

The mean \pm standard deviation intercostal tissue thicknesses were $3.64 \pm 0.25 \mathrm{~mm}, 4.31 \pm 0.18 \mathrm{~mm}$, and $2.18 \pm 0.69$ $\mathrm{cm}$ for the SD rats, LE rats, and York pigs, respectively.

The frequency range for all of the rat intercostal tissue attenuation coefficient measurements was between 3.1 and $9.6 \mathrm{MHz}$ in $0.5-\mathrm{MHz}$ increments (14 values per tissue sample), and for the pig intercostal tissue attenuation coefficients was between 3.1 and $8.6 \mathrm{MHz}$ in $0.5-\mathrm{MHz}$ increments (12 values per tissue sample). The increased frequency range for the rat intercostal tissue was possible because of the lower attenuation in these thinner samples; the measurement system's drive signal amplitude from the pulser/receiver was limited. Thus, for each of the eight rat chest walls, there were 14 frequencies and hence 14 attenuation coefficient values, or a total of 112 data points $(8 \times 14)$ for the linear regression analysis at each temperature. For the ten pig chest walls, there were a total of 120 data points $(10 \times 12)$ for the linear regression analysis at each temperature.

Graphical representation of the frequency-dependent attenuation coefficient regression functions is shown in Fig. 1 for the intercostal tissue from the chest walls of eight SD rats, eight LE rats, and ten York pigs, each at three temperatures, $\left(22,30\right.$, and $\left.37^{\circ} \mathrm{C}\right)$. The linear regression equations for the nine curves (Fig. 1) are:

$$
\begin{gathered}
\mathrm{A}=1.64 \mathrm{f}-1.32 \quad 8 \mathrm{SD} \text { rats at } 22^{\circ} \mathrm{C} \\
\text { frequency range: } 3.1-9.6 \mathrm{MHz} \\
\mathrm{n}=112, \mathrm{r}^{2}=0.72, \mathrm{SER}=2.1, \mathrm{SES}=0.096 \\
\mathrm{~A}=1.57 \mathrm{f}-1.70 \quad 8 \mathrm{SD} \text { rats at } 30^{\circ} \mathrm{C} \\
\text { frequency range: } 3.1-9.6 \mathrm{MHz} \\
\mathrm{n}=112, \mathrm{r}^{2}=0.76, \mathrm{SER}=1.8, \mathrm{SES}=0.085 \\
\mathrm{~A}=1.42 \mathrm{f}-1.22 \quad 8 \mathrm{SD} \text { rats at } 37^{\circ} \mathrm{C} \\
\text { frequency range: } 3.1-9.6 \mathrm{MHz} \\
\mathrm{n}=112, \mathrm{r}^{2}=0.67, \mathrm{SER}=2.0, \mathrm{SES}=0.095
\end{gathered}
$$




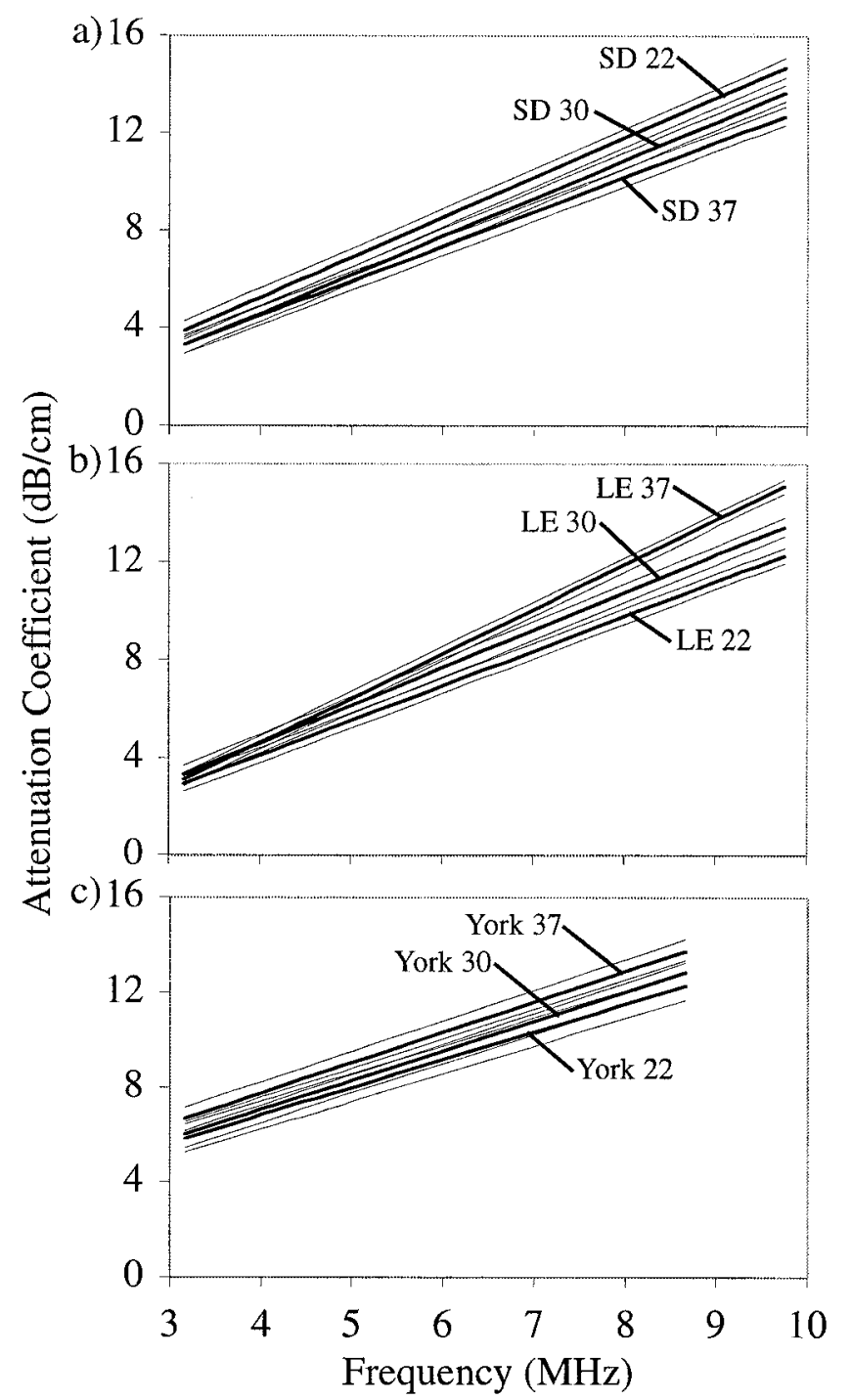

Fig. 1. Attenuation coefficient regression functions (linear regression lines $\pm 95 \%$ confidence band for the regression line) as a function of frequency for the intercostal tissues of (a) SD rats, (b) LE rats, and (c) York pigs. The numbers following SD, LE, and York denote the temperature $\left(22,30,37^{\circ} \mathrm{C}\right)$.

$$
\begin{gathered}
\mathrm{A}=1.42 \mathrm{f}-1.58 \quad 8 \mathrm{LE} \text { rats at } 22^{\circ} \mathrm{C} \\
\text { frequency range: } 3.1-9.6 \mathrm{MHz} \\
\mathrm{n}=112, \mathrm{r}^{2}=0.74, \mathrm{SER}=1.7, \mathrm{SES}=0.080 \\
\mathrm{~A}=1.53 \mathrm{f}-1.56 \quad 8 \mathrm{LE} \text { rats at } 30^{\circ} \mathrm{C} \\
\text { frequency range: } 3.1-9.6 \mathrm{MHz} \\
\mathrm{n}=112, \mathrm{r}^{2}=0.71, \mathrm{SER}=2.0, \mathrm{SES}=0.093 \\
\mathrm{~A}=1.82 \mathrm{f}-2.67 \quad 8 \mathrm{LE} \text { rats at } 37^{\circ} \mathrm{C} \\
\text { frequency range: } 3.1-9.6 \mathrm{MHz} \\
\mathrm{n}=112, \mathrm{r}^{2}=0.86, \mathrm{SER}=1.5, \mathrm{SES}=0.071 \\
\mathrm{~A}=1.16 \mathrm{f}+2.14 \quad 10 \text { York pigs at } 22^{\circ} \mathrm{C} \\
\text { frequency range: } 3.1-8.6 \mathrm{MHz} \\
\mathrm{n}=120, \mathrm{r}^{2}=0.28, \mathrm{SER}=3.3, \mathrm{SES}=0.17
\end{gathered}
$$

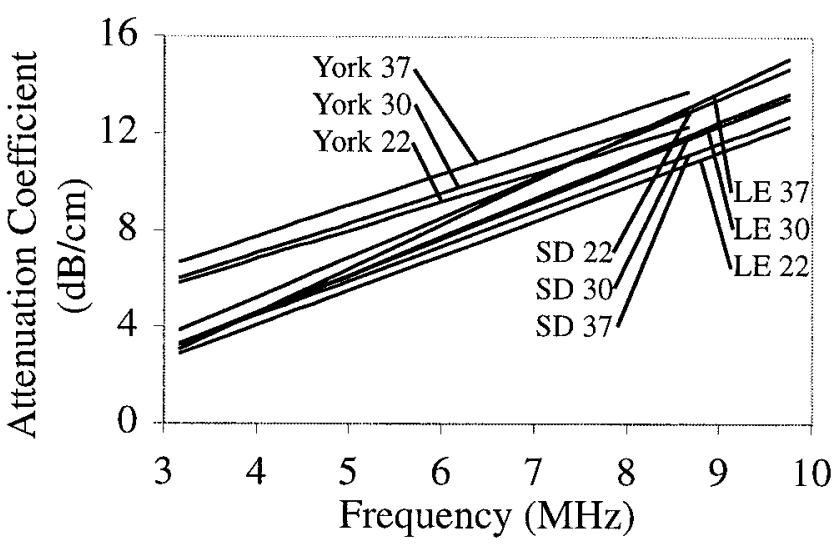

Fig. 2. All nine attenuation coefficient linear regression equations without the $\pm 95 \%$ confidence band for the regression line from Fig. 1.

$$
\begin{aligned}
& \mathrm{A}=1.24 \mathrm{f}+2.08 \quad 10 \text { York pigs at } 30^{\circ} \mathrm{C} \\
& \text { frequency range: } 3.1-8.6 \mathrm{MHz} \\
& \mathrm{n}=120, \mathrm{r}^{2}=0.35, \text { SER }=2.9, \text { SES }=0.15 \\
& A=1.29 \mathrm{f}+2.58 \quad 10 \text { York pigs at } 37^{\circ} \mathrm{C} \\
& \text { frequency range: } 3.1-8.6 \mathrm{MHz} \\
& \mathrm{n}=120, \mathrm{r}^{2}=0.39, \text { SER }=2.8, \text { SES }=0.15
\end{aligned}
$$

where the attenuation coefficient $(\mathrm{A})$ is in decibels per centimeter and the ultrasonic frequency (f) is in megahertz.

A power law fit also was determined for the above nine data sets, and are over the above indicated frequency range:

$$
\begin{array}{lll}
\mathrm{A}=0.99 \mathrm{f}^{1.18} & \mathrm{r}^{2}=0.74 & 8 \mathrm{SD} \text { rats at } 22^{\circ} \mathrm{C} \\
\mathrm{A}=0.87 f^{1.20} & \mathrm{r}^{2}=0.76 & 8 \mathrm{SD} \text { rats at } 30^{\circ} \mathrm{C} \\
\mathrm{A}=0.95 \mathrm{f}^{1.12} & \mathrm{r}^{2}=0.61 & 8 \mathrm{SD} \text { rats at } 37^{\circ} \mathrm{C} \\
\mathrm{A}=0.78 f^{1.20} & \mathrm{r}^{2}=0.82 & 8 \mathrm{LE} \text { rats at } 22^{\circ} \mathrm{C} \\
\mathrm{A}=0.85 f^{1.21} & \mathrm{r}^{2}=0.79 & 8 \mathrm{LE} \text { rats at } 30^{\circ} \mathrm{C} \\
\mathrm{A}=0.75 f^{1.32} & \mathrm{r}^{2}=0.90 & 8 \mathrm{LE} \text { rats at } 37^{\circ} \mathrm{C} \\
\mathrm{A}=2.42 \mathrm{f}^{0.71} & \mathrm{r}^{2}=0.26 & 10 \text { York pigs at } 22^{\circ} \mathrm{C} \\
\mathrm{A}=2.53 \mathrm{f}^{0.72} & \mathrm{r}^{2}=0.33 & 10 \text { York pigs at } 30^{\circ} \mathrm{C} \\
\mathrm{A}=2.81 \mathrm{f}^{0.71} & \mathrm{r}^{2}=0.37 & 10 \text { York pigs at } 37^{\circ} \mathrm{C}
\end{array}
$$

Comparison of the SD rat attenuation coefficients in the general model [27] for the three temperatures indicates that the three linear regressions are different $(\mathrm{p}<0.0001)$. Likewise, comparison of the LE rat attenuation coefficients in the general model [27] for the three temperatures indicates that the three linear regressions are different $(\mathrm{p}<0.0001)$. However, comparison of the York pig attenuation coefficients in the null model [27] for the three temperatures do not indicate that the three linear regressions are different $(\mathrm{p}=0.54)$. All nine linear regression equations without the $\pm 95 \%$ confidence band for the regression line are shown in Fig. 2.

Comparisons of the intercostal tissue attenuation coefficient $(\mathrm{dB} / \mathrm{cm}-\mathrm{MHz})$ data for the three temperatures were performed at the discrete frequencies of $3.1,6.2$, and 


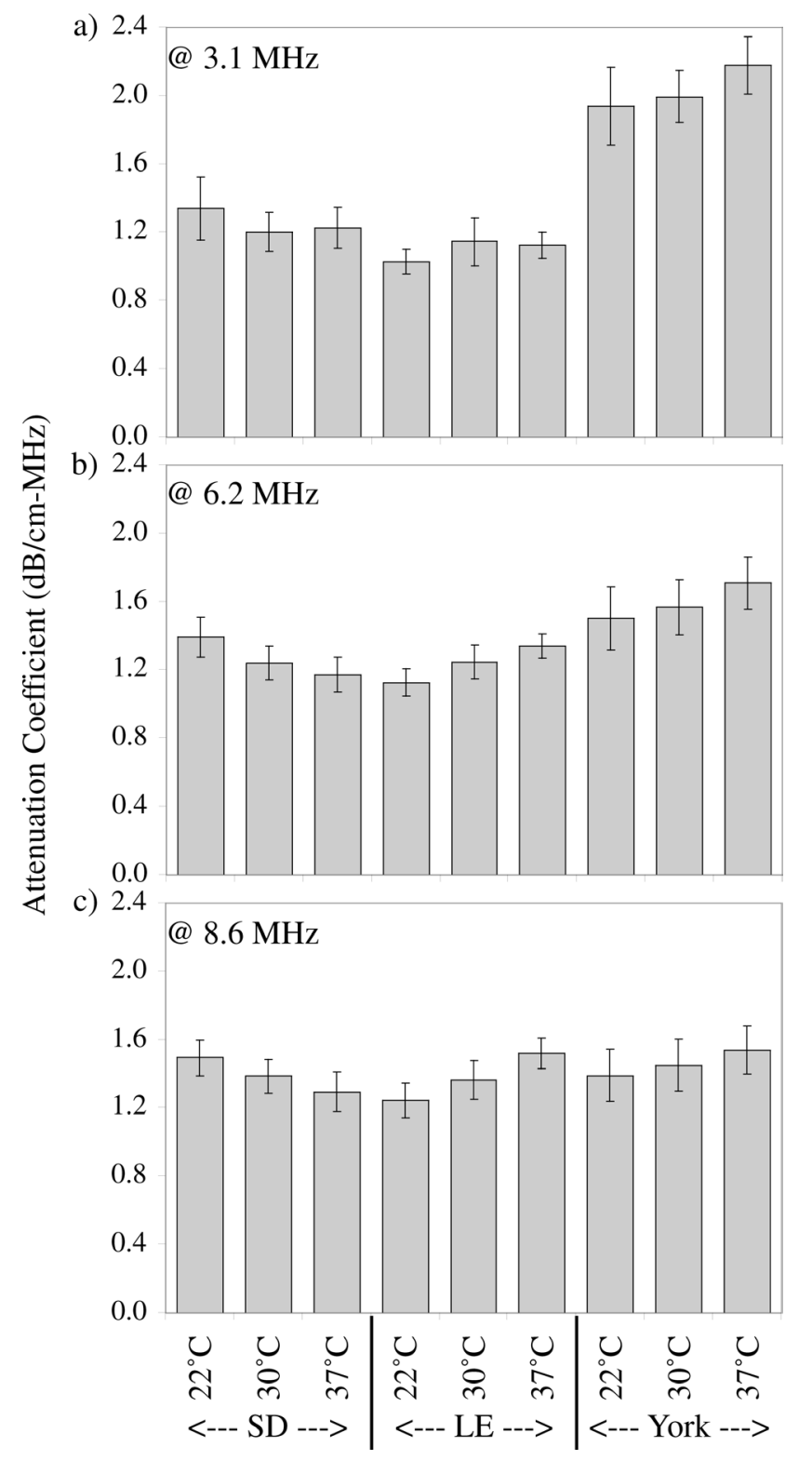

Fig. 3. The intercostal tissue attenuation coefficient at (a) $3.1 \mathrm{MHz}$, (b) $6.2 \mathrm{MHz}$, and (c) $8.6 \mathrm{MHz}$ for the three temperatures $(22,30$, $37^{\circ} \mathrm{C}$ ) for SD rats, LE rats, and York pigs. Error bars are standard errors of the mean.

8.6 MHz for each animal group (Fig. 3, Table I). A singlefactor Analysis of Variance (ANOVA) indicates that there is no statistically significant difference as a function of temperature. However, there were some significant differences (single-factor ANOVA) of the same temperature at the three frequencies.

Propagation speeds as a function of temperature for the three animal groups are shown in Fig. 4, and listed in Table II. A single-factor ANOVA indicates that there is no statistically significant difference as a function of temperature for the SD rat. However, the LE rat and York pig propagation speeds are different as a function of temperature.

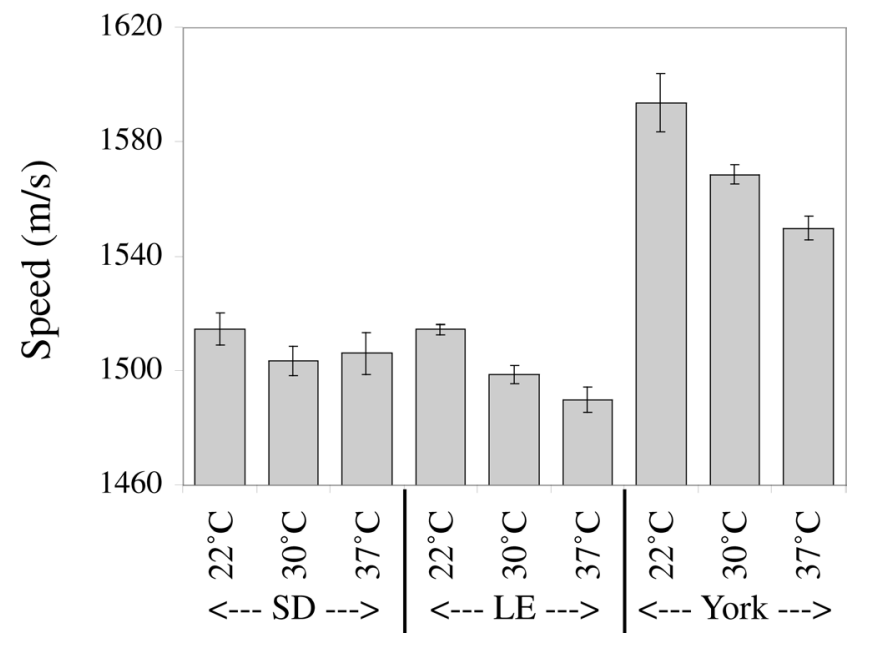

Fig. 4. The intercostal tissue propagation speed for the three temperatures $\left(22,30,37^{\circ} \mathrm{C}\right)$ for $\mathrm{SD}$ rats, LE rats, and York pigs. Error bars are standard errors of the mean.

\section{Discussion}

The temperature-dependent attenuation coefficient and propagation speed literature is quite sparse [28], [29]. There are no known reports for intercostal tissue of any species. One way to evaluate the temperature-dependent findings reported herein relative to the literature is to examine the temperature dependence of the different types of tissues that compose intercostal tissue. Intercostal tissue is composed of skin, panniculus muscle, subcutaneous adipose tissue [fat], and intercostal muscle, viz., skin, fat, and muscle. We have reported percentages (mean) of intercostal tissue constituents (skin, fat, and muscle content) for SD rats [22] and for crossbred pigs at three ages [30] (Table III).

Muscle is the major constituent of intercostal tissue. Muscle has a weak temperature-dependent attenuation coefficient that ranges between $-0.006 \mathrm{~dB} / \mathrm{cm} /{ }^{\circ} \mathrm{C}$ for canine heart muscle [31] and $+0.04 \mathrm{~dB} / \mathrm{cm} /{ }^{\circ} \mathrm{C}$ for bovine skeletal muscle [32]; and it has a relatively strong temperature-dependent propagation speed that ranges between $+0.6 \mathrm{~m} / \mathrm{s} /{ }^{\circ} \mathrm{C}$ for canine skeletal muscle [33] and $+2.9 \mathrm{~m} / \mathrm{s} /{ }^{\circ} \mathrm{C}$ for bovine skeletal muscle [32]. No reports are known for skin, but generally the temperature-dependent attenuation coefficient and propagation speed for most soft tissues are in the ranges of those just reported [29], that is, about $-0.05 \mathrm{~dB} / \mathrm{cm} /{ }^{\circ} \mathrm{C}$ and about $+1 \mathrm{~m} / \mathrm{s} /{ }^{\circ} \mathrm{C}$, respectively. Thus skin and muscle, which constitute about threefourths of intercostal tissue, tend to exhibit a positive temperature dependency for both attenuation coefficient and propagation speed.

However, fat, which constitutes about one-quarter of intercostal tissue, has a relatively strong but highly variable temperature-dependent attenuation coefficient that ranges between -0.08 and $-0.2 \mathrm{~dB} / \mathrm{cm} /{ }^{\circ} \mathrm{C}$ for porcine back fat [34], and between +0.09 and $-0.6 \mathrm{~dB} / \mathrm{cm} /{ }^{\circ} \mathrm{C}$ for bovine peritoneal fat [35]. Likewise, fat has a relatively strong temperature-dependent propagation speed that ranges be- 
TABLE I

Mean (standard error of the mean) Attenuation Coefficient Values of Intercostal Tissue as a Function of Temperature and Ultrasonic Frequency.*

\begin{tabular}{|c|c|c|c|c|}
\hline & \multicolumn{3}{|c|}{ Attenuation coefficient (dB/cm-MHz) } & \multirow{2}{*}{$\begin{array}{c}\text { Temperature } \\
\text { dependent } \\
\text { p-value }\end{array}$} \\
\hline & $@ 22^{\circ} \mathrm{C}$ & $@ 30^{\circ} \mathrm{C}$ & $@ 37^{\circ} \mathrm{C}$ & \\
\hline SD (@3.1 MHz) & $1.34(0.19)$ & $1.20(0.11)$ & $1.23(0.12)$ & 0.78 \\
\hline LE (@3.1 MHz) & $1.03(0.07)$ & $1.15(0.14)$ & $1.12(0.08)$ & 0.69 \\
\hline York (@3.1 MHz) & $1.94(0.23)$ & $1.99(0.15)$ & $2.18(0.17)$ & 0.64 \\
\hline SD (@6.2 MHz) & $1.39(0.12)$ & $1.24(0.10)$ & $1.17(0.10)$ & 0.34 \\
\hline LE (@6.2 MHz) & $1.13(0.08)$ & $1.25(0.10)$ & $1.34(0.07)$ & 0.22 \\
\hline York (@6.2 MHz) & $1.50(0.19)$ & $1.57(0.16)$ & $1.71(0.15)$ & 0.68 \\
\hline SD (@8.6 MHz) & $1.49(0.10)$ & $1.39(0.10)$ & $1.30(0.11)$ & 0.43 \\
\hline LE (@8.6 MHz) & $1.25(0.10)$ & $1.36(0.11)$ & $1.52(0.089)$ & 0.18 \\
\hline York (@8.6 MHz) & $1.39(0.15)$ & $1.45(0.15)$ & $1.54(0.14)$ & 0.77 \\
\hline SD frequency dependent p-value & 0.73 & 0.43 & 0.75 & \\
\hline LE frequency dependent p-value & 0.23 & 0.44 & 0.007 & \\
\hline York frequency dependent p-value & 0.12 & 0.05 & 0.02 & \\
\hline
\end{tabular}

*The specimens are from eight SD rats, eight LE rats, and ten York pigs. The temperature-dependent p-values are for that temperature-dependent row; the frequency-dependent p-values are for the frequencydependent columns where $\mathrm{n}=8$ for the SD rats, $\mathrm{n}=8$ for the LE rats, and $\mathrm{n}=10$ for the York pigs for each temperature.

TABLE II

Mean (standard error of the mean) Propagation Speed Values of Intercostal Tissue as a Function of Temperature.*

\begin{tabular}{lcccc}
\hline & \multicolumn{3}{c}{ Propagation speed $(\mathrm{m} / \mathrm{s})$} & \\
\cline { 2 - 4 } & $@ 22^{\circ} \mathrm{C}$ & @30 & \\
& $1515(6)$ & $1504(5)$ & $1506(7)$ & 0.42 \\
SD rats & $15157^{\circ} \mathrm{C}$ & p-value \\
LE rats & $1515(2)$ & $1499(3)$ & $1490(4)$ & 0.0001 \\
York pigs & $1594(10)$ & $1569(3)$ & $1550(4)$ & 0.0003 \\
\hline
\end{tabular}

*The specimens are from eight SD rats, eight LE rats, and ten York pigs. The p-values are for that temperature-dependent row where $\mathrm{n}=8$ for the SD rats, $\mathrm{n}=8$ for the LE rats, and $\mathrm{n}=10$ for the York pigs for each temperature.

TABLE III

Mean Percentages of Intercostal Tissue Constituents for Rats [22] And for Pigs [30].

\begin{tabular}{lcccc}
\hline Species & SD rat & $\begin{array}{c}\text { Crossbred } \\
\text { pig }\end{array}$ & $\begin{array}{c}\text { Crossbred } \\
\text { pig }\end{array}$ & $\begin{array}{c}\text { Crossbred } \\
\text { pig }\end{array}$ \\
\hline Age (days) & $42-49$ & $4-5$ & $27-30$ & $58-62$ \\
Skin content (\%) & 27 & 21 & 10 & 15 \\
Fat content (\%) & 12 & 24 & 37 & 19 \\
Muscle content (\%) & 61 & 54 & 52 & 66 \\
\hline
\end{tabular}

tween -2 and $-3 \mathrm{~m} / \mathrm{s} /{ }^{\circ} \mathrm{C}$ for canine stomach fat $[33]$ and between -7 and $-8 \mathrm{~m} / \mathrm{s} /{ }^{\circ} \mathrm{C}$ for bovine peritoneal fat [35]. Thus, fat, which constitutes about one-quarter of intercostal tissue, suggests a negative temperature dependency for both attenuation coefficient and propagation speed.

There was no temperature dependency of the intercostal tissue attenuation coefficients in either species at the discrete frequencies of 3.1, 6.2 and 8.6 MHz (Tables I and IV). However, when considering the linear regression analyses, there was a temperature dependency of the intercostal tissue attenuation coefficients in SD and LE rats, but there was no temperature dependency in York pigs. Generally, the attenuation coefficient increased as temperature decreased and increased for SD and LE rats, respectively, with the spread the greatest at the highest frequencies; the regression equations closely overlapped at the lowest frequencies. This result is shown quantitatively in Table IV in which the temperature-dependent attenuation coefficient becomes more negative as a function of frequency for the $\mathrm{SD}$ rats, and the temperature-dependent attenuation coefficient becomes more positive as a function of frequency for the LE rats.

Also, Table IV provides an explanation about why there was no temperature dependency of the intercostal tis- 
TABLE IV

Calculated Slopes of the Attenuation Coefficient (DB/Cm) vs. Temperature $\left({ }^{\circ} \mathrm{C}\right)$ from the Linear Regression Equations at Three Frequencies, and from the Same Discrete Frequencies.

\begin{tabular}{lccc}
\hline & $\mathrm{f}(\mathrm{MHz})$ & $\begin{array}{c}\text { Slope }\left(\mathrm{dB} / \mathrm{cm} /{ }^{\circ} \mathrm{C}\right) \\
(\text { regression })\end{array}$ & $\begin{array}{c}\text { Slope }\left(\mathrm{dB} / \mathrm{cm} /{ }^{\circ} \mathrm{C}\right) \\
(\text { discrete frequencies })\end{array}$ \\
\hline SD rat & 3.1 & -0.040 & -0.0076 \\
SD rat & 6.2 & -0.085 & -0.015 \\
SD rat & 9.6 & -0.13 & -0.013 \\
LE rat & 3.1 & 0.011 & 0.0065 \\
LE rat & 6.2 & 0.093 & 0.014 \\
LE rat & 9.6 & 0.18 & 0.019 \\
York pig & 3.1 & 0.055 & 0.016 \\
York pig & 6.2 & 0.082 & 0.014 \\
York pig & 8.6 & 0.10 & 0.0099 \\
\hline
\end{tabular}

TABLE V

Calculated Slopes of the Mean Propagation Speed (M/s) vs. Temperature $\left({ }^{\circ} \mathrm{C}\right)$.

\begin{tabular}{lc}
\hline & Slope $\left(\mathrm{m} / \mathrm{s} /{ }^{\circ} \mathrm{C}\right)$ \\
\hline SD rats & -0.59 \\
LE rats & -1.6 \\
York pigs & -2.9 \\
\hline
\end{tabular}

sue attenuation coefficients in either species at the discrete frequencies, but there was a temperature dependency of the intercostal tissue attenuation coefficients in $\mathrm{SD}$ and LE rats using the linear regression equations. The regression-based slope values for the York pigs were $\leq 0.1 \mathrm{~dB} / \mathrm{cm} /{ }^{\circ} \mathrm{C}$ over the spectrum for applicable frequencies; thus, the temperature-dependent attenuation coefficient did not change very much between 3.1 and $8.6 \mathrm{MHz}$. That is why there was no temperature dependency of the intercostal tissue attenuation coefficient for York pigs (the discrete-frequency slope values for the York pigs were even less). Likewise, the magnitudes of the regression-based slope values for the SD and LE rats were $\leq 0.1 \mathrm{~dB} / \mathrm{cm} /{ }^{\circ} \mathrm{C}$ at 3.1 and $6.2 \mathrm{MHz}$, and thus exhibited no temperature dependency of the intercostal tissue attenuation coefficients. However, when the highest applicable frequency was included in the analysis, as was the case for the linear regression analysis, the higher magnitudes of the regression-based slope values for the $\mathrm{SD}$ and $\mathrm{LE}$ rats were $>0.1 \mathrm{~dB} / \mathrm{cm} /{ }^{\circ} \mathrm{C}$, thus causing a sufficient temperature dependency to affect the statistical significance.

There was no temperature dependency of the intercostal tissue propagation speed in SD rats, but there was a temperature dependency in LE rats and York pigs. For the LE rats and York pigs, the propagation speed decreased as temperature increased. This result is shown quantitatively in Table $\mathrm{V}$ in which the temperature-dependent propagation speed is least negative for the SD rats, in between for the LE rats, and most negative for the York pigs.

Relative differences in tissue constituents could explain the temperature dependence and the temperature independence of both the attenuation coefficient and propaga- tion speed of intercostal tissue. The nonfat tissue generally has a positive temperature dependence for both attenuation coefficient and propagation speed, but fat tissue generally has a negative temperature dependence for both. For the SD rats with a negative temperature-dependent attenuation coefficient (Table IV) and slight but not significant negative temperature-dependent propagation speed (Table V), fat tissue might be considered to have a weak contribution on the ultrasonic propagation properties. For the LE rats with a positive temperature-dependent attenuation coefficient (Table IV) and a negative temperaturedependent propagation speed (Table V), the role of fat tissue and nonfat tissue appear to have competing effects on different ultrasonic propagation properties. Likewise, for the York pigs, there was a slight but not significant positive temperature-dependent attenuation coefficient (Table IV) and a negative temperature-dependent propagation speed (Table V). Here also, the role of fat tissue and nonfat tissue appear to have competing effects on different ultrasonic propagation properties. It also is possible that the distribution of the tissue constituents throughout the intercostal tissue had an effect on the ultrasonic propagation properties. For example, even though the concentration of the tissue constituents were not too different for these species, the York pig had significantly greater attenuation coefficients and propagation speeds than the two rat strains. Also, although the intercostal tissues of all species evaluated herein have a negative temperaturedependent propagation speed, the intercostal tissues of LE rats and York pigs had a positive temperature-dependent attenuation coefficient. These observations may be due to distribution of the tissue constituents, and the exact type of the specific tissues cannot be discounted, particularly the type of fat tissue.

\section{Conclusions}

The primary purpose of this study was to estimate the temperature dependence of the intercostal tissue's attenuation coefficient so that accurate estimates of the in situ (at the pleural surface) acoustic pressure levels could be 


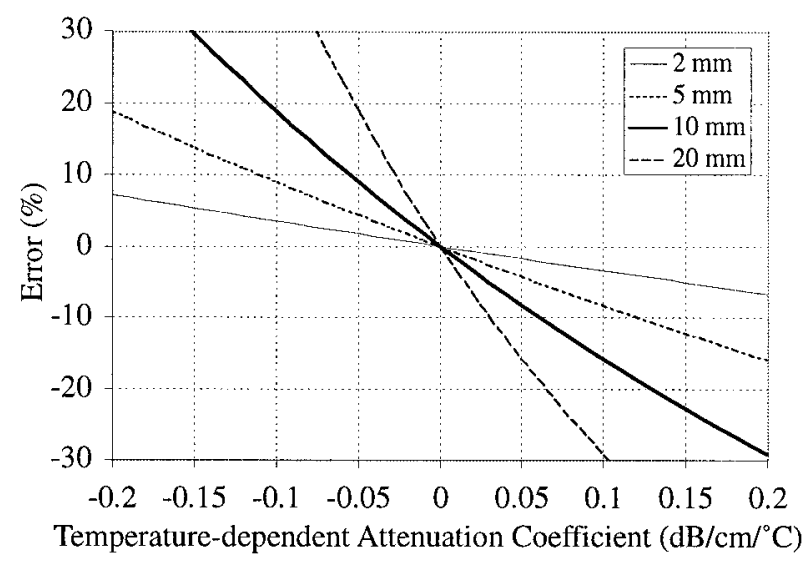

Fig. 5. The in situ (at the pleural surface) acoustic pressure error at $37^{\circ} \mathrm{C}$ from intercostal tissue measurements at $22^{\circ} \mathrm{C}$ as a function of the temperature-dependent attenuation coefficient for four intercostal tissue thicknesses.

made for our ultrasound-induced lung hemorrhage studies. The in situ acoustic pressure is calculated from the in vitro (water-based) acoustic pressure measurement using the expression $p_{\text {in situ }}=p_{\text {in vitro }} \mathrm{e}^{-\mathrm{Ad}}$ where $\mathrm{A}$ is the attenuation coefficient and $\mathrm{d}$ is the intercostal tissue thickness. As a worse-case example, the SD rats used in a previous study [19] had a maximum intercostal tissue thickness of $4.2 \mathrm{~mm}$, and $\mathrm{p}_{\text {in situ }}$ was calculated from an attenuation coefficient of $1.1 \mathrm{~dB} / \mathrm{cm}-\mathrm{MHz}$, which was independently measured at a temperature of $22^{\circ} \mathrm{C}$ [22]. An intercostal tissue thickness of $6 \mathrm{~mm}$ will be used with this example. For a temperature-dependent attenuation coefficient at $3.1 \mathrm{MHz}$ of $-0.02 \mathrm{~dB} / \mathrm{cm} /{ }^{\circ} \mathrm{C}$ (a discretefrequency value of $-0.0076 \mathrm{~dB} / \mathrm{cm} /{ }^{\circ} \mathrm{C}$ was determined, see Table IV), which would yield an $\mathrm{p}_{\text {in situ value at }}$ $37^{\circ} \mathrm{C}$ that is in error by $+2.1 \%$ relative to not taking into consideration the temperature-dependent attenuation coefficient. Using the temperature-dependent attenuation coefficient at $6.2 \mathrm{MHz}$ of $-0.03 \mathrm{~dB} / \mathrm{cm} /{ }^{\circ} \mathrm{C}$ (a discretefrequency value of $-0.015 \mathrm{~dB} / \mathrm{cm} /{ }^{\circ} \mathrm{C}$ was determined, see Table IV), the error would be $3.2 \%$. As a worse-case example for a larger intercostal tissue thickness of $20 \mathrm{~mm}$, using the temperature-dependent attenuation coefficient at $3.1 \mathrm{MHz}$ of $+0.025 \mathrm{~dB} / \mathrm{cm} /{ }^{\circ} \mathrm{C}$ (a discrete-frequency value of $+0.016 \mathrm{~dB} / \mathrm{cm} /{ }^{\circ} \mathrm{C}$ was determined for York pigs, see Table IV), the error would be $-8.3 \%$. These errors are within the measurement uncertainty of the calibration procedure. Thus, it is not necessary to determine the attenuation coefficient of intercostal tissue at body temperature $\left(37^{\circ} \mathrm{C}\right)$, but rather it is sufficient to determine the attenuation coefficient at room temperature $\left(22^{\circ} \mathrm{C}\right)$. Fig. 5 shows these errors as a function of the intercostal tissue thickness and temperature-dependent attenuation coefficient.

\section{ACKNOWLEDGMENTS}

We thank Professor D. Simpson for statistical analysis advice, Dr. C. Frazier for assistance in developing the anal- ysis programs, and J. Blue, K. Norrell, and B. Zierfuss for their technical contributions.

\section{REFERENCES}

[1] S. Z. Child, C. L. Hartman, L. A. Schery, and E. L. Carstensen, "Lung damage from exposure to pulsed ultrasound," Ultrasound Med. Biol., vol. 16, pp. 817-825, 1990.

[2] C. Hartman, S. Z. Child, R. Mayer, E. Schenk, and E. L. Carstensen, "Lung damage from exposure to the fields of an electrohydraulic lithotripter," Ultrasound Med. Biol., vol. 16, pp. $675-679,1990$.

[3] C. H. Raeman, S. Z. Child, and E. L. Carstensen, "Timing of exposures in ultrasonic hemorrhage of murine lung," Ultrasound Med. Biol., vol. 19, pp. 507-517, 1993.

[4] D. P. Penney, E. A. Schenk, K. Maltby, C. Hartman-Raeman, S. Z. Child, and E. L. Carstensen, "Morphologic effects of pulsed ultrasound in the lung," Ultrasound Med. Biol., vol. 19, pp. 127135,1993

[5] L. A. Frizzell, E. Chen, and C. Lee, "Effects of pulsed ultrasound on the mouse neonate: Hind limb paralysis and lung hemorrhage," Ultrasound Med. Biol., vol. 20, pp. 53-63, 1994.

[6] A. F. Tarantal and D. R. Canfield, "Ultrasound-induced lung hemorrhage in the monkey," Ultrasound Med. Biol., vol. 20, pp. 65-72, 1994.

[7] J. F. Zachary and W. D. O'Brien, Jr., "Lung lesion induced by continuous- and pulsed-wave (diagnostic) ultrasound in mice, rabbits, and pigs," Vet. Pathol., vol. 32, pp. 43-54, 1995.

[8] G. H. Harrison, H. A. Eddy, J.-P. Wang, and F. Z. Liberman, "Microscopic lung alterations and reduction of respiration rate in insonated anesthetized swine," Ultrasound Med. Biol., vol. 21, pp. 981-983, 1995.

[9] C. K. Holland, C. X. Deng, R. E. Apfel, J. L. Alderman, L. A. Ferandez, and K. J. W. Taylor, "Direct evidence of cavitation in vivo from diagnostic ultrasound," Ultrasound Med. Biol., vol. 22, pp. 917-925, 1996.

[10] R. Baggs, D. P. Penney, C. Cox, S. Z. Child, C. H. Raeman, D. Dalecki, and E. L. Carstensen, "Thresholds for ultrasonically induced lung hemorrhage in neonatal swine," Ultrasound Med. Biol., vol. 22, pp. 119-128, 1996.

[11] C. H. Raeman, S. Z. Child, D. Dalecki, C. Cox, and E. L. Carstensen, "Exposure-time dependence of the threshold for ultrasonically induced murine lung hemorrhage," Ultrasound Med. Biol., vol. 22, pp. 139-141, 1996.

[12] W. D. O'Brien, Jr. and J. F. Zachary, "Lung damage assessment from exposure to pulsed-wave ultrasound in the rabbit, mouse, and pig," IEEE Trans. Ultrason., Ferroelect., Freq. Contr., vol. 44, pp. 473-485, 1997.

[13] D. Dalecki, S. Z. Child, C. H. Raeman, C. Cox, and E. L. Carstensen, "Ultrasonically induced lung hemorrhage in young swine," Ultrasound Med. Biol., vol. 23, pp. 777-781, 1997.

[14] D. Dalecki, S. Z. Child, C. H. Raeman, C. Cox, D. P. Penney, and E. L. Carstensen, "Age dependence of ultrasonically induced lung hemorrhage in mice," Ultrasound Med. Biol., vol. 23, pp. 767-776, 1997.

[15] W. D. O'Brien, Jr., L. A. Frizzell, R. M. Weigel, and J. F. Zachary, "Ultrasond-induced lung hemorrhage is not caused by inertial cavitation," J. Acoust. Soc. Amer., vol. 108, pp. 1290$1297,2000$.

[16] J. F. Zachary, J. M Sempsrott, L. A. Frizzell, D. G. Simpson, and W. D. O'Brien, Jr., "Superthreshold behavior and threshold estimation of ultrasound-induced lung hemorrhage in adult mice and rats," IEEE Trans. Ultrason., Ferroelect., Freq. Contr., vol. 48, pp. 581-592, 2001.

[17] W. D. O'Brien, Jr., L. A. Frizzell, D. J. Schaeffer, and J. F. Zachary, "Superthreshold behavior of ultrasound-induced lung hemorrhage in adult mice and rats: Role of pulse repetition frequency and exposure duration," Ultrasound Med. Biol., vol. 27, pp. $267-277,2001$.

[18] J. F. Zachary, L. A. Frizzell, K. S. Norrell, J. P. Blue, R. J. Miller, and W. D. O'Brien, Jr., "Temporal and spatial evaluation of lesion resolution following exposure of rat lung to pulsed ultrasound," Ultrasound Med. Biol., vol. 27, pp. 829-839, 2001.

[19] W. D. O'Brien, Jr., D. G. Simpson, L. A. Frizzell, and J. F. Zachary, "Superthreshold behavior and threshold estimates of ultrasound induced lung hemorrhage in adult rats: Role of 
beamwidth," IEEE Trans. Ultrason., Ferroelect., Freq. Contr., vol. 48, pp. 1695-1705, 2001.

[20] J. M. Kramer, T. G. Waldrop, L. A. Frizzell, J. F. Zachary, and W. D. O'Brien, Jr., "Cardiopulmonary function in rats with lung hemorrhage induced by exposure to superthreshold pulsed ultrasound," J. Med. Ultrasound, vol. 20, pp. 1197-1206, 2001.

[21] W. D. O'Brien, Jr., J. M. Kramer, T. G. Waldrop, L. A. Frizzell R. J. Miller, J. P. Blue, and J. F. Zachary, "Ultrasound-induced lung hemorrhage: Role of acoustic boundary conditions at the pleural surface," J. Acoust. Soc. Amer., vol. 111, pp. 1102-1109, 2002.

[22] G. A. Teotico, R. J. Miller, L. A. Frizzell, J. F. Zachary, and W. D. O'Brien, Jr., "Attenuation coefficient estimates of mouse and rat chest wall," IEEE Trans. Ultrason., Ferroelect., Freq. Contr., vol. 48, pp. 593-601, 2001.

23] E. L. Madsen, F. Dong, G. R. Frank, B. S. Gara, K. A. Wear T. Wilson, J. A. Zagzebski, H. L. Miller, K. K. Shung, S. H. Wang, E. J. Feleppa, T. Liu, W. D. O'Brien, Jr., K. A. Topp, N. T. Sanghvi, A. V. Zaitsen, T. J. Hall, J. B. Fowlkes, O. D. Kripfgans, and J. G. Miller, "Interlaboratory comparison of ultrasonic backscatter, attenuation and speed measurements," $J$. Med. Ultrasound, vol. 18, pp. 615-631, 1999.

[24] K. Raum and W. D. O'Brien, Jr., "Pulse-echo field distribution measurement technique of high-frequency ultrasound sources," IEEE Trans. Ultrason., Ferroelect., Freq. Contr., vol. 44, pp. 810-815, 1997.

[25] L. E. Kinsler, A. R. Frey, A. B. Coppens, and J. V. Sanders, Fundamentals of Acoustics. 4 ed. New York: Wiley, 2000, p. 121.

[26] J. Neter, M. H. Kutner, C. J. Nachtsheim, and W. Wasserman, Applied Linear Statistical Models. 4 ed. Chicago: Irwin, 1996, pp. 3-94.

[27] J. Neter, M. H. Kutner, C. J. Nachtsheim, and W. Wasserman, Applied Linear Statistical Models. 4 ed. Chicago: Irwin, 1996, pp. 1019-1027.

[28] M. J. Haney and W. D. O'Brien, Jr., "Temperature dependency of ultrasonic propagation properties in biological materials," in Tissue Characterization with Ultrasound. vol. I, J. F. Greenleaf, Ed. Boca Raton, FL: CRC Press, 1986, pp. 15-55.

[29] F. A. Duck, Physical Properties of Tissue. A Comprehensive Reference Book. New York: Academic, 1990.

[30] R. J. Miller, L. A. Frizzell, J. F. Zachary, and W. D. O'Brien, Jr., "Attenuation coefficient and propagation speed estimates of intercostal tissue as a function of pig age," IEEE Trans. Ultrason., Ferroelect., Freq. Contr., vol. 49, no. 10, pp. 1421-1429, 2002.

[31] M. O'Donnell, J. W. Mimbs, B. E. Sobel, and J. G. Miller, "Ultrasonic attenuation of myocardial tissue: Dependence on time after excision and on temperature," J. Acoust. Soc. Amer., vol. 62 , pp. 1054-1057, 1977.

[32] N. B. Smith, "Effect of myofibril length and tissue constituents on acoustic propagation properties of muscle," Ph.D. dissertation, University of Illinois, Urbana, IL, 1996.

[33] R. L. Nasoni, T. Bowen, W. G. Connor, and R. R. Sholes, "In vivo temperature dependence of ultrasound speed in tissue and its application to noninvasive temperature monitoring," Ultrason. Imag., vol. 1, pp. 34-43, 1979.

[34] P. M. Gammell, D. H. LeCroisette, and R. C. Heyser, "Temperature and frequency dependence of ultrasonic attenuation in selected tissues," Ultrasound Med. Biol., vol. 5, pp. 269-277, 1979.

[35] J. C. Bamber and C. R. Hill, "Ultrasonic attenuation and propagation speed in mammalian tissues as a function of temperature," Ultrasound Med. Biol., vol. 5, pp. 149-157, 1979.

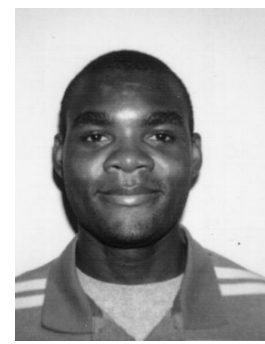

Rene T. Towa was born in Gobo, city of Maroua, Cameroon. He received the B.S. degree in Bioengineering with honors from the University of Illinois at Urbana-Champaign in May 2001. He is currently working towards the M.S. degree in Biomedical Engineering at the University of Michigan at Ann Arbor, MI. During his undergraduate studies, $\mathrm{Mr}$. Towa was a Howard Hughes Undergraduate Research Fellow from Summer 2000 to Spring 2001.

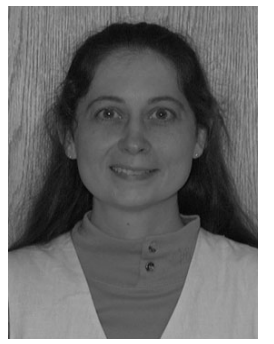

Rita J. Miller was born in San Diego, California. She received her D.V.M. at the University of Wisconsin, Madison in 1992.

Dr. Miller completed a small animal medical/surgical internship at the University of Illinois at Urbana-Champaign in 1993. She then worked as a Veterinary Poison Information Specialist at the National Animal Poison Control Center, also at the University of Illinois at Urbana-Champaign. While at the University of Illinois she has been involved with a variety of research projects. Evaluation of the efficacy of a new treatment for Erlichiosis in dogs. Rehabilitation with electrical muscle stimulation for dogs with surgically treated cranial cruciate ligament deficient stifles. Role of IGF-1 (insulin-like growth factor 1) and the IGF-1R (type one insulin-like growth factor one receptor) in the uterotrophic effect induced by the administration of tamoxifen. Identification and cloning of canine MMP-2 (matrix metalloproteinase-2). RT-PCR (reverse-transcription polymerase chain reaction) profiling of canine spontaneous tumors for the presence of MMP-2. Her current research involves the assessment of ultrasound-induced lung damage and attenuation coefficient determination of intercostal tissues.

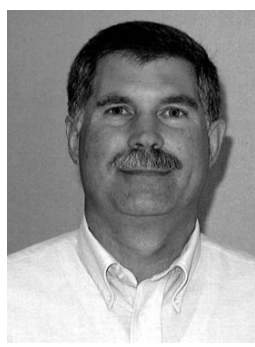

Leon A. Frizzell (S'71-M'74-SM'82) was born in West Stewartstown, NH, on September 12,1947 . He received the B.S. degree in physics from the University of New Hampshire, Durham, NH, in 1969, and the M.S. and $\mathrm{Ph} . \mathrm{D}$. degrees in electrical engineering from the University of Rochester, Rochester, NY, in 1971 and 1976, respectively.

Since 1975, he has been in the Department of Electrical and Computer Engineering at the University of Illinois at Urbana-Champaign, where he is currently Professor of Electrical and Computer Engineering and of Bioengineering. He was Acting Director of the Bioacoustics Research Laboratory within the Department of Electrical and Computer Engineering from August, 1989 to August, 1990 and served as Chair of the Bioengineering Faculty from August, 1995 to December, 1999. He was also a Visiting Research Scientist at Yale University from Aug, 1985 to August, 1986. His research interests are in ultrasound and include tissue characterization, biological effects, hyperthermia, surgery and bioengineering.

Dr. Frizzell is a Fellow of the American Institute of Ultrasound in Medicine, Fellow of the Acoustical Society of America, Fellow of the American Institute for Medical and Biological Engineering, and is a member of Eta Kappa $\mathrm{Nu}$ and Sigma Xi.

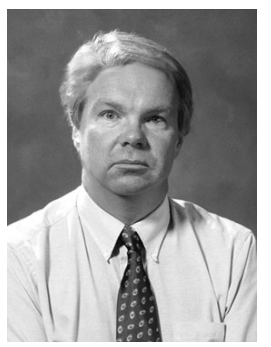

James F. Zachary received the B.S. degree from Northern Illinois University, Dekalb in 1972 and D.V.M and Ph.D. degrees in 1977 and 1983, respectively, from the University from Illinois, Urbana-Champaign. From 1978, he has been at the University of Illinois, where he is a Professor of Pathology and a Bioengineering Faculty Member. His research interests involve ultrasound-tissue interactions and include biological effects, tissue characterization, blood-flow measurements, acoustic microscopy, and microbubble contrast agents. He has published more than 75 papers. Dr. Zachary has served as Editor-in-Chief of Veterinary Pathology and is currently a coeditor of the textbook Thomson's Special Veterinary Pathology. $\mathrm{He}$ is a Diplomate of the American College of Veterinary Pathologists and a member of the American Institute of Ultrasound in Medicine (AIUM), the American Society for Investigative Pathology (ASIPFASEB), and the Society for Neuroscience. He currently serves as vice-chair of the AIUM Bioeffects Committee. 


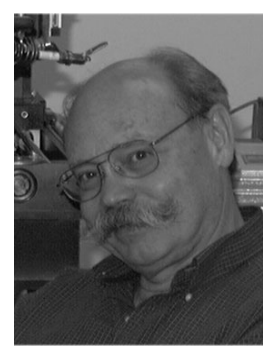

William D. O'Brien, Jr. (S'64-M'70SM'79-F'89) received the B.S., M.S., and Ph.D. degrees in 1966, 1968, and 1970, from the University of Illinois, Urbana-Champaign.

From 1971 to 1975 he worked with the Bureau of Radiological Health (currently the Center for Devices and Radiological Health) of the U.S. Food and Drug Administration. Since 1975 , he has been at the University of Illinois, where he is a Professor of Electrical and Computer Engineering and of Bioengineering, College of Engineering; Professor of Bioengineering, College of Medicine; Professor of Nutritional Sciences, College of Agricultural, Consumer and Environmental Sciences; a Research Professor in the Beckman Institute for Advanced Science and Technology; and a Research Professor in the Coordinated Science Laboratory. He is the Director of the Bioacoustics Research Laboratory. His research interests involve the many areas of ultrasound-tissue interaction, including spectroscopy, risk assessment, biological effects, tissue characterization, dosimetry, blood-flow measurements, acoustic microscopy and imaging for which he has published 240 papers.

Dr. O'Brien is a Fellow of the Institute of Electrical and Electronics Engineers, the Acoustical Society of America and the American Institute of Ultrasound in Medicine, and a Founding Fellow of the American Institute of Medical and Biological Engineering. He was recipient of the IEEE Centennial Medal (1984), the AIUM Presidential Recognition Awards (1985 and 1992), the AIUM/WFUMB Pioneer Award (1988), the IEEE Outstanding Student Branch Counselor Award for Region 4 (1989), the AIUM Joseph H. Holmes Basic Science Pioneer Award (1993), and the IEEE Ultrasonics, Ferroelectrics, and Frequency Control Society Distinguished Lecturer (1997-1998). He received the IEEE Ultrasonics, Ferroelectrics, and Frequency Control Society's Achievement Award for 1998, and the IEEE Millennium Medal in 2000. He has served as Co-Chair of the 1981 and 2001 IEEE Ultrasonic Symposia, and General Chair of the 1988 IEEE Ultrasonics Symposium. He is Co-Chair of the 2003 IEEE Ultrasonics Symposium. He has been Secretary-Treasurer (19721980), Vice President (1981), and President (1982-1983) of the IEEE Sonics and Ultrasonics Group (currently the IEEE Ultrasonics, Ferroelectrics, and Frequency Control Society), and Editor-in-Chief of the IEEE Transactions on Ultrasonics, Ferroelectrics, and Frequency Control (1984-2001). He has been Treasurer (1982-1985), PresidentElect (1986-1988) and President (1988-1991) of the American Institute of Ultrasound in Medicine. He has served on the Board of Directors (1988-1993) of the American Registry of Diagnostic Medical Sonographers, and has been Treasurer (1991-1994) of the World Federation for Ultrasound in Medicine and Biology. 